\title{
THE IMPACT OF ROLE-PLAY TECHNIQUE ON THE STUDENTS' ENGLISH SPEAKING SKILL
}

\author{
Nichella Ayu Clarita \\ University of Technology Yogyakarta \\ nichellaayu@gmail.com \\ Indah Rahmawati \\ University of Technology Yogyakarta \\ indahh050998@gmail.com \\ Solikin Sudibyo \\ University of Technology Yogyakarta \\ sudibyo355@gmail.com
}

\begin{abstract}
Many students usually find it hard to speak in English, because they have not practiced enough. This reason makes them cannot speak English well. Speaking is the skill which student should master it in order to communicate with other people. The situation in the learning process is one of the important things that the teacher should consider. This research aims to know; (1) the students' achievement of the third semester of English Education Department at the University of Technology Yogyakarta in speaking English using role-play technique on academic year 2018/2019, and (2) the influencing factors to the students' speaking skill achievement using roleplay technique. The method used was quantitative method with experimental design to 9 students as the research sample. The data were analysed using Microsoft Excel 2013. The findings indicated that the mean score increased from 70 to 78.88 , the standard deviation also improved from 6.123 to 7.817. Furthermore, the data from questionnaire indicated that the students had positive responses toward the use of role-play technique. Therefore, the use of role-play technique can improve the students' speaking ability at this experimental research.
\end{abstract}

Keywords: Speaking, skill, language, learning

\section{A. INTRODUCTION}

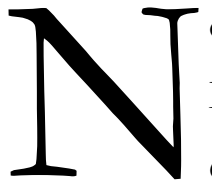

ot all students can speak in English well, especially for us who live in Indonesia. Many students face difficulties to speak in English because they have not practiced enough. At a particular time, they cannot speak in English even one word of it.

Danielson et al. (2002) stated that the way in learning a language should involve listening skill first, then followed by speaking and finally the writing of the language. In the earlier stages, English teaching should be focused on the involvement of the listening and speaking skills.

Speaking skill is the most important ability to learn English well. Linse (2005) stated that every young English language students can read and write in English after they master speaking skills. To the students, there are some problems in learning speaking skills. The students are too shy and afraid to take part in the conversation. Another reason is the lack of motivation to practice English in daily conversation which is caused it difficult to use it effectively. Furthermore, the teachers must use a strategy to minimalize these insufficiencies.

Through practice, students can improve their speaking skills better than before. The practice is the right way to improve speaking skills. To improve the students' speaking skill, the 
teacher can use several techniques. Larsen (2000: 68) stated that role play is important in the communicative approach because it allows the learners an opportunity to practice how to communicate in different social contexts. Hence, teachers should know the suitable technique to improve students' abilities.

The objectives of this research are; (1) to know the students' achievement in speaking English using role-play technique, and (2) to know the influencing factors of the students' speaking skill achievement using role-play technique. Not only presenting about the students' achievement, but also showing the influencing factors of the students' speaking skill achievement, which other researcher may have not touched it yet.

\section{B. REVIEW OF LITERATURE}

Tarigan (1990: 3-4) defined that speaking is a language skill developed in a child's life, produced by listening skill, in that period speaking skill is learned. Remembering that the English language in Indonesia is a foreign language, it is impossible if the students learned about speaking in English when they were child. To improve students' speaking ability, the teachers and the students have to work together to reach the goal of speaking ability. Since Curriculum 2013 has a significant impact on the way of teaching and learning, the teachers should find suitable techniques.

According to Harmer (2001), speaking is divided into two categories. First is accuracy, it is a kind of facet which is covering the language feature, such as the suitable use of vocabulary, grammar, and pronunciation. The second is fluency, which related to mental processing that represents the capability of maintaining speaking in a real-life context and processing information. Students' speaking ability is the skill that students should have to complete four skills in English, such as speaking, listening, writing, and reading skills.

The students and the teachers need solutions directly to feel the advantages of learning materials by experiencing and learning about speaking skill. In the learning process, role-play involves students by allowing them to act as figures in a fancied or real scheme. It is a technique that complements the traditional teachers and assignment format of tertiary level Social Science learning (Manorom and Pollock, 2006). In a role-play, the teachers select a particular event or situation that students learn.

According to Brierly, Devonshire, and Hillman (2002), the role-play technique develops functioning knowledge i.e. a combination of propositional knowledge (knowing about the academic knowledge base), and procedural knowledge (knowing how - having the skills), as a benefit of role-play activities which can make students both more independent and confident. Then, 
students can also participate in teaching and learning activities to practice their ability to speak in public and can learn how to think critically through speaking skill.

Role-play is an important technique in teaching speaking which can be used by teachers. Whether in social contexts or social roles, it gives students the opportunity to practice in communicating. According to Hatting (1993: 165), role-play would seem to be an ideal activity where students could use their English effectively to stimulate a conversation situation and give them an opportunity to practice and develop their communication skill. In doing role play, students also may feel doing great activities, because they can act like professional people.

Maria A. Kodotchigova (2002) explains step by step to make a role-play. The first is the situation for a role-play. The teachers should keep students' interest by letting students to choose the situation. The second is role-play design, to come up with ideas on how this situation may develop. The third is linguistic preparation. The teachers must predict the language needed for it. The fourth is factual preparation. This step means teacher provides a clear information and complete role description about the scheme or figure that is played by the students. The fifth is assigning the roles. The last is follow up. This step does not mean pointing out and correcting mistakes.

Ladousse (2004) explains there are several types of roles. The first is the roles with corresponding to real need in the students' lives. The second type of roles is the students played themselves a variety of situation with may or may not have direct experience. The third type is the type that few students will ever experience directly themselves. The last is fantasy roles, which are fictitious, imaginary, and possible even absurd. Each type of role can be implied in the classroom and can make students active more.

\section{METHOD}

This research used quantitative method using experimental design in order to find a certain result of the students' speaking skill. The sample of this research was divided into two groups. This research was conducted to 9 students of the $3^{\text {rd }}$ semester at English Education Department in University of Technology Yogyakarta. They were treated using role play technique. Independent variable of this research was the use of role play technique, and dependent variable was the students' speaking ability.

\section{Instrument}


There are two instruments were used in this research namely test and questionnaire. The first, the students were tested to speak and imitate the environment duties using the text dialog. This activity was the students' pre-test and post-test. The pre-test and post-test are similar but in the post-test students imitate without text dialog. The second, this research used questionnaire that consisted of 14 questions which explored the students' interest in the learning process toward the use of role-play technique.

\section{Procedure}

Before starting the test, researchers divided 9 students into 2 groups. Each group consisted of 4 students and 5 students. The students were given dialogue and they watched videos related to the material. Procedures of data collections were: (1) the researcher gave the pre-test to the students through role-play as a technique. The score was taken by looking at the fluency, accuracy, pronunciation, and intonation of the students' speaking. (2) In post-test, the researchers asked the students to practice the conversations in a group based on the situation given. The first group was given text A, which was a classroom situation. In this situation, one student became a teacher, and 3 others became the students. They acted in the teaching and learning process in the classroom. Meanwhile, the second group was given text B, which was a restaurant situation. This situation was a condition which made the student became a waitress and guests.

\section{Rubric of Assessment}

The following table is the classification score used in this research to find the students' speaking skill both in pre-test and post-test:

Table 1. Score Classification

\begin{tabular}{|c|c|c|}
\hline \multicolumn{3}{|c|}{ Students' Score Classification } \\
\hline Aspect & Categories & $\begin{array}{c}\text { Score } \\
\text { qualification }\end{array}$ \\
\hline \multirow[t]{5}{*}{ Fluency } & 1. Very smooth, like native speakers & $85-100$ \\
\hline & 2. The speaking seems a bit disturbed by language problems & $75-80$ \\
\hline & 3. The speaking seems disturbed by language problems quite a lot & $65-70$ \\
\hline & 4. The speaking hesitant and stalled due to language limitations frequently & $55-60$ \\
\hline & $\begin{array}{l}\text { 5. The speaking is interrupted and stopped then the conversation is not } \\
\text { possible }\end{array}$ & $00-50$ \\
\hline \multirow[t]{5}{*}{ Vocabulary } & 1. Use vocabularies and expressions like native speakers & $85-100$ \\
\hline & 2. Sometimes use inappropriate vocabularies & $75-80$ \\
\hline & 3. often use inappropriate vocabularies & $65-70$ \\
\hline & 4. Use wrong vocabularies so that it's difficult to understand & $55-60$ \\
\hline & 5. Vocabulary is very limited so the conversation is not possibly happened & $00-50$ \\
\hline \multirow[t]{5}{*}{ Pronunciation } & 1. Easy to understand and has native speaker accents & $85-100$ \\
\hline & 2. Easy to understand even though only have a certain accents & $75-80$ \\
\hline & 3. There is a problem of speaking that makes the listener must concentrate & $65-70$ \\
\hline & 4. Difficult to understand because there is a pronunciations' problem & $55-60$ \\
\hline & 5. There are pronunciations' problems so that couldn't be understood & $00-50$ \\
\hline
\end{tabular}


Clarita, Rahmawati, Sudibyo, The Impact of Role-Play....

\begin{tabular}{|l|l|c|}
\hline Understanding & 1. Understand all conversation without problems & $85-100$ \\
\hline & $\begin{array}{l}\text { 2. Understand all conversations, even though there are repetitions in cer- } \\
\text { tain parts }\end{array}$ & $75-84$ \\
\hline & $\begin{array}{l}\text { 3. Understand the most of conversation even though there are several } \\
\text { conversations }\end{array}$ & $65-74$ \\
\hline & 4. Hard to follow what is said in the conversations & $55-64$ \\
\hline & 5. could not understand even though it's only a simple conversations & $00-54$ \\
\hline
\end{tabular}

Based on the students' score classification above, the speaking ability of the students was calculated to find the students' individual score, mean score, standard deviation, and range both in pre-test and post-test using by Microsoft Excel 2013. Then, the students' scores of pre-test and post-test $\mathrm{t}$ were classified into 5 categories as follows:

Table 2. Score Category

\begin{tabular}{|c|c|}
\hline Score & Category \\
\hline $85-100$ & Excellent \\
\hline $75-84$ & Very good \\
\hline $65-74$ & Good \\
\hline $55-64$ & Poor \\
\hline $00-54$ & Very poor \\
\hline
\end{tabular}

The questionnaire at the experimental group was analysed using Likert Scale as follow:

Table 3. Questionnaire Score Classification

\begin{tabular}{|c|c|}
\hline Score & Classification \\
\hline $90-100$ & Strongly Positive \\
\hline $80-89$ & Positive \\
\hline $60-79$ & Nearly Positive \\
\hline $50-69$ & Negative \\
\hline $0-49$ & Strongly Negative \\
\hline
\end{tabular}

\section{FINDING AND DISCUSSION}

1. The pre-test and post-tests' calculations were gathered from minimum to maximum. The students' maximal and minimum scores was presented on table 4:

Table 4. The minimum and maximum score of the students with statistic descriptive

\begin{tabular}{|l|r|l|r|}
\hline \multicolumn{1}{|c|}{ Pre-test } & \multicolumn{1}{|c|}{ Post test } & \\
\hline Minimum & 60 & Minimum & 65 \\
\hline Maximum & 80 & Maximum & 90 \\
\hline Confidence Level (95\%) & 4.70711123 & Confidence Level (95\%) & 6,008955 \\
\hline
\end{tabular}


Table 4 illustrated that the confidence level was $95 \%$ and the minimum of pre-test at this research increased from 60 to 65 on the post-test. In the same word, it happened in maximum score of the students too. The maximum pre-test and the post-test improved from 80 to 90 .

2. The students' individual scores on pre-test and post-test were presented on table below:

Table 5. Students' individual score of pre-test and post-test

\begin{tabular}{cccc}
\hline \multicolumn{2}{c}{ Pre-test } & \multicolumn{2}{c}{ Post-test } \\
\hline Mean score & Classification & Mean score & Classification \\
\hline 66 & Good & 70 & Good \\
78 & Very Good & 79 & Very Good \\
83 & Very Good & 81 & Very Good \\
69 & Good & 73 & Good \\
69 & Good & 71 & Good \\
71 & Good & 71 & Good \\
75 & Good & 76 & Very Good \\
69 & Good & 70 & Good \\
73 & Good & 74 & Good \\
\hline
\end{tabular}

3. Score of the Range, Mean, and Standard Deviation of pre-test and post-test in the experiment were derived from Microsoft Excel 2013 and illustrated as table below.

Table 6. Descriptive Statistics

\begin{tabular}{|l|r|r|}
\hline Statistics & Pre-test & \multicolumn{1}{|c|}{ Post-test } \\
\hline Mean & 70 & 78,88888889 \\
Standard & & \\
Deviation & 6,123724357 & 7,8173596 \\
Range & 20 & 25 \\
Minimum & 60 & 65 \\
Maximum & 80 & 90 \\
Sum & 630 & 710 \\
Count & 9 & 9 \\
\hline
\end{tabular}

The range score at the experimental group increased from 20 at the pre-test, it turned to 25 at the post-test. It indicated that the range data from experiment group was getting wider. The same thing seems at the minimum score at the experiment, it also increased from 60 to 65 . In the maximum score of pre-test and post-test at the experiment, it increased from 80 to 90 . The total score at experiment group increased from 630 to 710 . The mean scores also increased which was 70 to 78.88 . The mean of the pre-test was categorized good and the post-test was categorized very good. On the same side, the standard deviation of this experiment improved from 6.123 of the pre-test to 7.817 at the post-test. 
4. Calculation of the significance score of pre-test and post-test at the experiment can be seen at the table below:

Table 7. T-test students' score

\begin{tabular}{|l|r|r|}
\hline \multicolumn{1}{|c|}{ Statistic } & pre-test & post-test \\
\hline Mean & 70 & 78.88888889 \\
Variance & 37.5 & 61.11111111 \\
Observations & 9 & 9 \\
Pearson Correlation & 0.587512089 & \\
Hypothesized Mean Differ- & 0 & \\
ence & 8 & \\
Df & -4.097180158 & \\
t Stat & 0.001725588 & \\
P(T<=t) one-tail & 1.859548038 & \\
t Critical one-tail & 0.003451177 & \\
P(T<=t) two-tail & 2.306004135 & \\
t Critical two-tail & \\
\hline
\end{tabular}

The table 7 explained that about 0.003 the significance score of the pre-test and post-test. From the category of significance score $0.003<0.05$, it meant that there were difference mean between the score of pre-test and post-test.

\section{Students' speaking achievement}

Based on the students' score classification, it concluded that the students' pre-test results were good. On the pre-test, 7 students were categorized as good and 2 students were categorized as very good. The individual score of the student showed that student one got 66 which was categorized as good. Meanwhile, student two and three got better, the score was 78 and 83 which was categorized as very good. However, student four, five, and six decreased which was categorized just as good with score 69 . On the same hand, student seven got better with score 71 which followed by student eight and nine, with the score 75 and 73 which was categorized as good.

After treatment on the post-test, the treatment group achieved a significant improvement mean score where 3 students were categorized as very good, and 6 students were categorized as good. In this section, no student was categorized as poor and very poor. The mean score of all students in the pre-test is 70 . Meanwhile, in the post-test, the mean score of all students was increased, with the score 78.88. A significant difference result of pre-test and post-test on t-test students' score was at the experimental result that was 0.003 . From the category of significance score $0.003<0.05$, it indicated that there were influences on the use of role-play to improve the students' speaking ability. 
Volume 6, Number 1, June 2020

\section{The factors influencing students' achievement in speaking English using role-play technique}

In accordance with the result of the speaking test, the researchers found some factors which influence the students' achievement in speaking English. Those factors were described based on the questionnaire which had been responded by the students. This is the close-ended questionnaire that consisted of 14 items. The analysis result is represented below.

Table 8 Students' interest using role-play

\begin{tabular}{lccc}
\hline \multicolumn{1}{c}{ Classification } & Range & Frequency & Percentage \\
\hline Strongly positive & $90-100$ & 1 & $12 \%$ \\
Positive & $80-89$ & 5 & $55 \%$ \\
Nearly positive & $60-79$ & 3 & $33 \%$ \\
Negative & $50-69$ & - & - \\
Strongly Negative & $0-49$ & - & - \\
\hline Total & & $\mathbf{9}$ & $\mathbf{1 0 0 \%}$ \\
\hline
\end{tabular}

Related to the result of the questionnaire, there was $12 \%$ of the students' score categorized as strongly positive. It means only 1 student included in this category. Although, in the positive category, there were 5 students or 55\% and 3 students or 33\% whose categorized as nearly positive. However, there was no student who was categorized as negative and strongly negative. The data above explained that most students had positive responses toward the use of role-play technique as a learning strategy.

Table 9. Mean score of students' questionnaire

\begin{tabular}{cc}
\hline Group & Mean Score \\
\hline Experiment & 79.96 \\
\hline
\end{tabular}

From the table 9 explained that the mean of the students' attitude at the experiment was 79.96. Related to the questionnaire data analysis, the researcher examined some factors which influenced the students' achievement in speaking English using role-play technique. There were 3 points influencing the achievement of the $3^{\text {rd }}$ semester students at English Education Department of Education Faculty in University of Technology Yogyakarta academic year 2018/2019 in speaking English using role-play technique.

First, table 8 showed that 3 of 9 students or 33\% nearly interest in speaking using the roleplaying technique. It indicated that it still had a lack of the students' interest in speaking English. They only need a little more motivation to improve their English-speaking ability. Thus, in order to be able to speak English fluently, the students must interest in English subject especially in 
speaking. Second, table 8 showed that 5 of 9 students or $55 \%$ had a positive interest in speaking using role-play technique. It meant that the students' achievement still had a chance to be improved. The third, table 9 showed that the mean score of the questionnaire was 79.96 which categorized as nearly good. It meant that the students have a positive agreement about applying role-play techniques in the learning process in order to improve their speaking skill.

\section{E. CONCLUSION AND SUGGESTION}

The aim of this paper had been to examine the impact of the role-ply technique on English speaking skill in the third-semester students at the University of Technology Yogyakarta. Related to findings of students' mean scores and questionnaires that had been presented, it was found that the mean of the pre-test was 70 with 6.123 of the standard deviation. Meanwhile, in the post-test, the mean score of the students was 78.88 with 7.817 of standard deviation.

Based on the questionnaires' mean score, the overall mean score for students' interest was 79.96. Thus, it could be concluded that the impact of the role-play technique of the thirdsemester students at the English Education Department of Faculty of Education in University of Technology Yogyakarta, academic year 2018/2019 in speaking was almost good with total means score 78.88 after using the technique. Furthermore, the researchers find 3 factors influencing the role-play technique toward the achievement of students' speaking English using role-play technique. First, students had nearly low interest in practicing English speaking. Second, students still had a chance to improve their English skill and achievement. Third, the students were still not accustomed in using the role-playing technique. Therefore, the teacher should use role-play techniques in order to improve and practice more students' speaking skill.

\section{REFERENCES}

Abubakar, M.S. (2015). Improving the Second Year Students' Speaking Ability Through ProjectBased Learning (PBL) At MTSN Model Makasar. English, Teaching, Learning, and Research Journal. 1 (2).

Brierley, Gery.et al. (2002). Learning To Participate," Responding To Changes In Australian Land And Water Management Policy And Practice". Australian Journal of Environment Education. 18 (4).

Danielson, L, et al. (2002). Identification of Learning Disabilities: Research to Practice. New York: Routledge.

Harmer, Jeremy. (2001). The Practice of English Language Teaching. Third edition. Longman Pearson Education Limited. 
Volume 6, Number 1, June 2020

Manorom, Kanokwan \& Zoë Pollock. (2006). Role Play as a Teaching Method: A Practical Guide. Bangkok: The Mekong Learning Initiative and the Mekong Sub-region Social Research Centre, Faculty of Liberal Arts, Ubon Ratchathani University.

Kardiansyah, M.Y., \& Qodriani, L. U. (2018). English Extracurricular And Its Role To Improve Students’ English Speaking Ability. Retorika: Jurnal Ilmu Bahasa. 4 (1).

Kodotchigova, Maria A. (2002). Role Play in Teaching Culture: Six Quick Steps for Classroom Implementation.

Ladousse, G.P. (2004). Role Play: Resources Book for the Teacher Series. New York: Oxford University Press.

Larsen, D. \& Freeman. (2000). Technique and Principle in Language Teaching. New York: Oxford University Press.

Linse, C., \& David Nunan. (2005) Practical Language Teaching: Young Learners. McGraw-Hill Education.

Lumettu A., \& Runtuwene L. (2017). Developing The Students' English Speaking Ability Through Impromptu Speaking Method. The Journal of Physic Conference Series. 953 (1).

Maulizan \& Safalinda, Nurfajri. (2016). The Implementation of Role Play Technique in Teaching Speaking (An Experimental Study To The First Year Students Of SMP N 8 Naga Raya). Getsempena English Education Journal 3(1).

Media, Zaky. (2013). "Definition of Speaking Skill (Skripsi Pendidikan Bahasa Inggris Gratis)".

Putri, A.A., \& Hariyati, H.S. (2016). Improving Students' Speaking Ability By Using Role Play At Seventh Grade Of Darul Mahdeeyah, Thailand. Prosiding International Conference On Education. 1 (1).

Samsibar \& Naro, Samsudin. (2018). The Effectiveness of Role Play Method toward Students' Motivation In English Conversation. English, Teaching, Learning, and Research Journal. 4 (1).

Sumpana. (2010). “Improving The Students' Speaking Skill By Role Play: A Classroom Action Research On The Eleventh Grade Students of Immersion Program 1of The State Senior High School of Karangpandan Academic Year 2009/2010".THESIS. Magister of Language Study. Muhammadiyah University of Surakarta.

Tarigan, G.(1990). Pengajaran Analisis Kesalahan Berbahasa. Bandung: Angkasa. 